\title{
IMPACT ANALYSIS OF AIRBORN POLLUTION DUE TO MAGNESIUM SLAG DEPOSIT AND CLIMATIC CHANGES CONDITION
}

\author{
WPLYW ŻUŻLU Z PRODUKCJI MAGNEZU \\ I ZMIAN KLIMATYCZNYCH \\ NA ZANIECZYSZCZENIE POWIETRZA
}

\begin{abstract}
The impact of airborne pollution by slag from magnesium production was analyzed under different climate conditions. The slag is characterized by X-ray diffraction analysis, scanning electron microscopy, differential thermal analysis and atomic absorption analysis. The dominant phase was the $\gamma$ modification of dicalcium silicate $\left(\gamma-2 \mathrm{CaO} \mathrm{SiO}_{2}\right)$ with significant amounts of perclas $(\mathrm{MgO})$, gehlenite $-2 \mathrm{CaO} \mathrm{Al}_{2} \mathrm{O}_{3} \mathrm{SiO}_{2}$, akermanite $-2 \mathrm{CaO} \mathrm{MgO} 2 \mathrm{SiO}_{2}$ and portlandite $\mathrm{Ca}(\mathrm{OH})_{2}$. The granulometric composition of the slag was within the range of $100 \times 10^{-3} \div 0.090 \times 10^{-3} \mathrm{~m}$. Ad hoc measurements were performed on site in June at 300 and $600 \mathrm{~m}$ distance from the slag deposit, which showed high Total Suspended Particles (TSP) concentrations. Imputing the results of an experimental investigation of the dust emission for wind velocities of 5,7 , and $10 \mathrm{~m} / \mathrm{s}$ and within the range of relative humidity from $10 \div 50 \%$ into SCREENVIEW software, the obtained values on the diagram showed good agreement with those of measurements on site. The simulation, that considered the landscape and wind increases over a 20 year period, showed that the dust concentration will be over the Maximum Allowable Concentration (MAC) up to $1400 \mathrm{~m}$ from the deposit, for an average wind speed of $3.0 \mathrm{~m} / \mathrm{s}$, a relative humidity of $37 \%$ and up to $4000 \mathrm{~m}$ under unstable weather conditions.
\end{abstract}

Keywords: magnesium slag, air pollution, dust emission, modelling

\section{Introduction}

Air pollution by fine solid particles from mining, ore processing and metallurgy waste deposits are evident in all regions where mining and metallurgy are in operation. The WHO guidelines provide interim targets for countries that still have very high levels of air pollution to encourage the gradual reduction of emissions [1]. In the Environment and Security Initiative Project: Mining in South-East Europe [2], it was concluded that almost the full range of warning signals for environmentally damaging incidents of large scale consequence are present in the region. These include large (historical) milling and

\footnotetext{
${ }^{1}$ Faculty of Technical Sciences, University in Pristina, Knjaza Milosa 7, 38220 Kos. Mitrovica, Serbia

${ }^{2}$ Faculty of Technology and Metallurgy, University of Belgrade, Karnegijeva 4, 11120, Belgrade, Serbia

*Corresponding author: jeladjokic7@gmail.com
} 
metallurgy plants with significant slag deposits, mountainous terrain; abandoned sites with little or no closure or control; lack of ongoing physical and/or biochemical monitoring of operational and/or abandoned sites; lack of ongoing maintenance, both proactive and reactive.

Magnesium slag is a by-product generated in the production of metallic magnesium. The magnesium slag produced by the Mg-Serbian Company is obtained in the reduction of synthesized dolomite by $\mathrm{FeSi}$, resulting in several oxides that combine amongst themselves, and is largely constituted of dicalcium silicate $\left(2 \mathrm{CaO} \cdot \mathrm{SiO}_{2}\right)$. Magnesium slag, in which the sum of the oxides $\mathrm{CaO}$ and $\mathrm{MgO}$ constitute $47 \%$ of the total mass, can be used as a soil correction additive in agriculture [3]. The remaining amount is stocked in open areas, increasing its environmental impact. The slag was characterized for its utilization as a construction material [4]. For this particular slag, investigations of the slag formation were performed [5, 6]. All these studies refer to granulated slag.

The environmental impact of dust in an integrated air quality system was analyzed by using different modeling systems [7]. The negative environmental impact of the magnesium slag deposit of the $\mathrm{Mg}$-Serbian Company was always assumed, but there was a need for detailed confirmation of the range of its impact. This necessity was raised by the Beekeeping Association, which started legal action against the Mg-Serbian Company, claiming that its production was endangered by magnesium production. The main objective of this study was to assess the concentrations of total suspended particles (TSP) and particulate matter $(\mathrm{PM})$ with an aerodynamic diameter $\leq 10 \mu \mathrm{m}\left(\mathrm{PM}_{10}\right)$ [8]. As no monitoring of the TSP and PM had previously been conducted, a simulation of the polluted area was made in order to determine the range and level of their environmental impact on human health and the ecosystem, with particular attention paid to the National Park Kopaonik and Spa, situated 7-15 km air distance from the company.

\section{Experimental procedure}

In order to determine the environmental impact of the magnesium slag deposit, slag samples were characterized by chemical, physical and mineralogical investigations. The dust loading factor was determined in a laboratory and then the climate factor was taken into consideration.

The chemical composition of the slag was determined by X-ray fluorescence measurements (ARL86480). The scanning electron microscopy, SEM, investigation was performed on a JEOL instrument (JSM6460) coupled to an energy dispersive spectrometer, EDS, (Oxford Instruments). X-ray diffraction, XRD, analysis was used for the mineralogical investigation. A Philips PW 1710 diffractometer was used under the following conditions: radiation from a copper anticathode with $\mathrm{CuK} \alpha=1.54178 \AA$ and graphite monochromator, working voltage $U=40 \mathrm{kV}$, current strength $I=30 \mathrm{~mA}$. The samples were investigated in the range of $5 \div 70^{\circ} 2 \theta$ (with step of $0.02^{\circ}$ and time $0.5 \mathrm{~s}$ ). The granulometric composition is determined on a BXF type cyclosizer.

Air-transmitted particulate matter (including TSP and $\mathrm{PM}_{10}$ ) was collected during the period $1^{\text {st }}-10^{\text {th }}$ June at sites located at different distances from the waste deposit in all directions. The slag deposit is situated in Baljevac, south-western Serbia at $475 \mathrm{~m}$ above sea level. Ambient air samples of TSP and $\mathrm{PM}_{10}$ particles for analysis were collected on glass fiber filters $(203 \times 254 \mathrm{~mm})$ using high-volume air samplers (GMV Inc., average flow rate 
$1.40 \pm 0.05 \mathrm{~m}^{3} \mathrm{~min}^{-1}$ for TSP and $1.39 \pm 0.05 \mathrm{~m}^{3} \mathrm{~min}^{-1}$ for $\mathrm{PM}_{10}$ ). A high volume air sampler is considered a reliable instrument for measuring the weight of TSP and $\mathrm{PM}_{10}$ in ambient air. After the air samples were collected, the loaded filters were returned to the laboratory and conditioned as before, and then the particle mass was determined gravimetrically by weighing the filters after drying for $48 \mathrm{~h}$ in a desiccator.

A fan type ABVE-3,5 apparatus was employed for measuring dust loading $\left[\mathrm{mg} / \mathrm{m}^{2}\right]$ in the laboratory, using a flow of $3600 \mathrm{~m}^{3} / \mathrm{h}$ and a vacuum of $200 \mathrm{~Pa}$ for airflow simulation, with a gravimetric sampler of the respiratory dust. The sample was set in a shallow metal plate, along with the measuring scale for the residual solid particles on the filter paper and a digital anemometer (DA-4000). The measurements were performed with the material set in the airflow direction from the fan and before the apparatus for polluted air vacuuming. The wind velocity was changed by the distance between the fan and the metal plate for each sample. The measurements were performed in wind velocities of 5,7 and $10 \mathrm{~m} / \mathrm{s}$. A wind velocity larger than $10 \mathrm{~m} / \mathrm{s}$ is outside the interval of wind velocities occurring in this region. The humidity in the laboratory was within the interval of $37 \div 53 \%$ and the dust concentration was $0 \%$.

The meteorological data for the last twenty years was taken from the nearest meteorological station, Josanicka Spa, $7 \mathrm{~km}$ from the site. The data was analyzed using the program Wind Rose Plot for Meteorological Data, Version 7.0.

\section{Results and discussion}

In the process of magnesium metal production, the produced magnesium furnace slag may be allowed to cool slowly after exiting the furnace, when the slag decrepitates into a powder. If the slag after discharge from the furnace is cooled quickly by contact with water, a granulated slag is formed with "sand-like" particles. The first type of slag, "unhydrated slag", was investigated in this study to determine the possible threat of its powder-like particles to the environment.

\section{Chemical composition analysis}

Chemical compositions of twenty slag samples were investigated using X-ray fluorescence analysis. The obtained results, including the detected concentration ranges and the average concentration of slag components, are given in Table 1.

Table 1

Chemical composition of the slag [wt. \%]

\begin{tabular}{|c|c|c|c|}
\hline Compound & Concentration range [\%] & Average value [\%] & Analyzed sample [\%] \\
\hline $\mathrm{SiO}_{2}$ & $23.43 \div 24.25$ & 23.84 & 24.24 \\
\hline $\mathrm{Al}_{2} \mathrm{O}_{3}$ & $11.16 \div 12.61$ & 11.885 & 11.79 \\
\hline $\mathrm{Fe}_{2} \mathrm{O}_{3}$ & $0.18 \div 0.62$ & 0.4 & 0.55 \\
\hline $\mathrm{CaO}$ & $51.59 \div 52.84$ & 52.215 & 52.35 \\
\hline $\mathrm{MgO}$ & $5.88 \div 8.82$ & 7.35 & 6.82 \\
\hline $\mathrm{Na}_{2} \mathrm{O}$ & $0.34 \div 0.39$ & 0.365 & 0.36 \\
\hline $\mathrm{K}_{2} \mathrm{O}$ & $0.01 \div 0.03$ & 0.02 & 0.017 \\
\hline $\mathrm{S}$ & $0.08 \div 0.15$ & 0.115 & 0.095 \\
\hline Others & $7.32 \div 0.32$ & 3.82 & 3.778 \\
\hline
\end{tabular}

${ }^{*} \mathrm{Zn}, \mathrm{Cu}, \mathrm{TiO}_{2}, \mathrm{Mn}_{2} \mathrm{O}_{3}$ and $\mathrm{SO}_{3}$ 


\section{Mineralogical analysis}

Mineralogical investigation of the slag was realized using XRD analysis and the obtained results are shown in Figure 1.

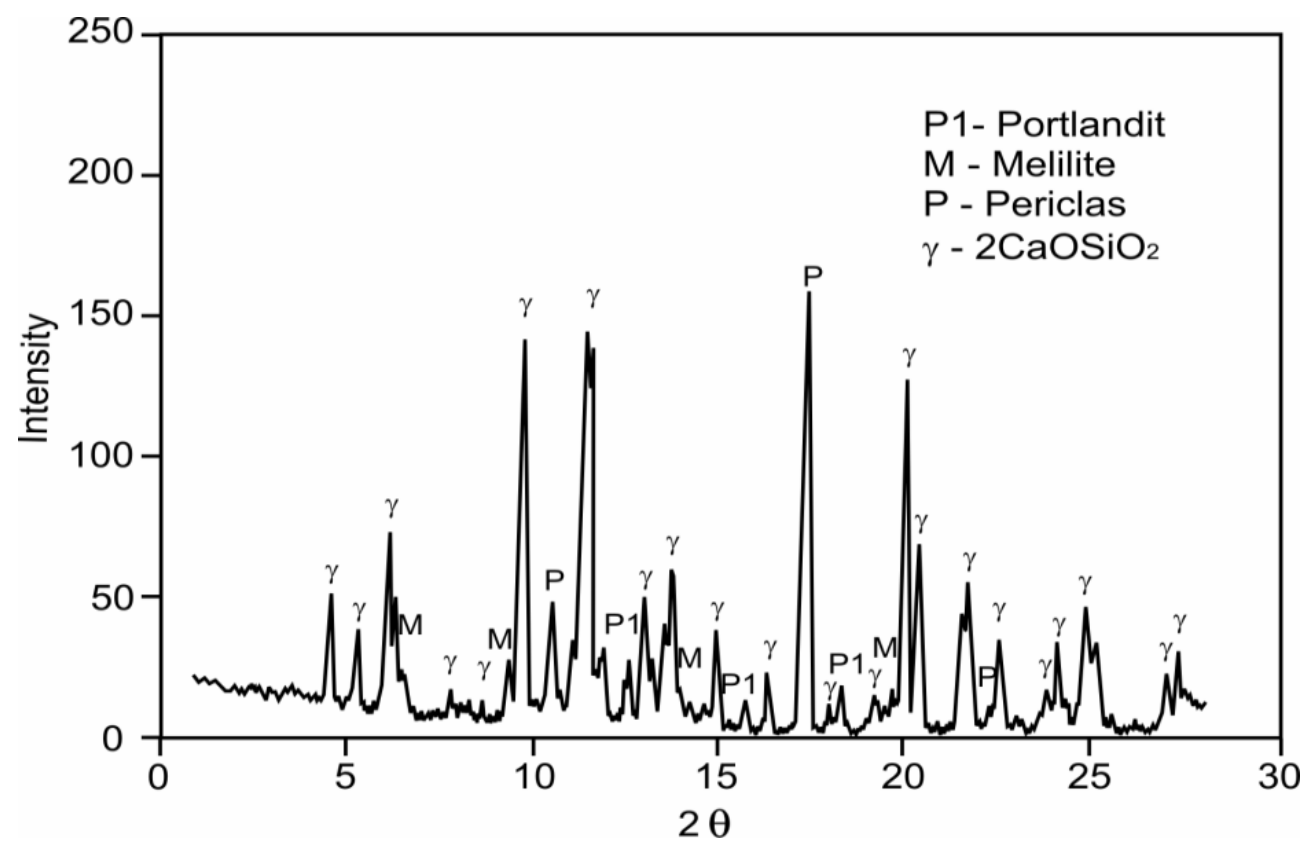

Fig. 1. A representative X-ray diffractogram of a slag sample

A dominant amount of the $\gamma$ modification of dicalcium silicate $(\gamma-2 \mathrm{CaO} \mathrm{SiO})_{2}$, formed from $\beta-2 \mathrm{CaO} \mathrm{SiO} \mathrm{S}_{2}$ by polymorph modification during the cooling phase of unhydrated slag, was registered by X-ray diffractometry. There was also a significant amount of Periclase $(\mathrm{MgO})$. In addition, interferent reflections of Melilite $\left(\mathrm{Ca}(\mathrm{Al}, \mathrm{Mg}, \mathrm{Si}) \mathrm{Si}_{2} \mathrm{O}_{7}\right)$, and a solid solution of Gehlenite $\left(2 \mathrm{CaO} \mathrm{Al}{ }_{2} \mathrm{O}_{3} \mathrm{SiO}_{2}\right)$ and Akermanite $\left(2 \mathrm{CaO} \mathrm{MgO} 2 \mathrm{SiO}_{2}\right)$ were clearly observed. There were also reflections for the mineral Portlandite $\left(\mathrm{Ca}(\mathrm{OH})_{2}\right)$.

\section{Microstructure analysis}

Microstructure of slag with characteristic maps of elements distribution and line scans are given in the further chapters. The microstructure of a slag sample with characteristic maps for the distribution of $\mathrm{Ca}, \mathrm{Si}$ and $\mathrm{Al}$ are shown in Figure 2. Mapping and line scanning analysis of the investigated slag are in agreement with the results of the mineralogical analysis. The map of calcium distribution is characterized by the existence of a number of regions with different concentrations. Silicon was present over the entire microstructure surface. The map of aluminium distribution displayed regions with a very small amount of aluminum, which corresponded well to the regions with the lowest magnesium concentrations. 

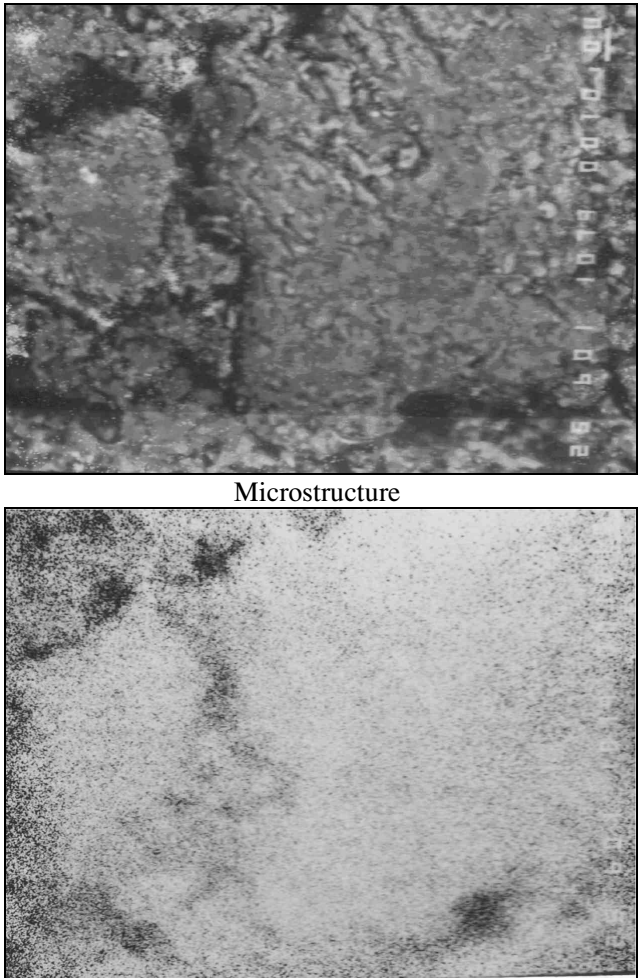

$\mathrm{Ca}$

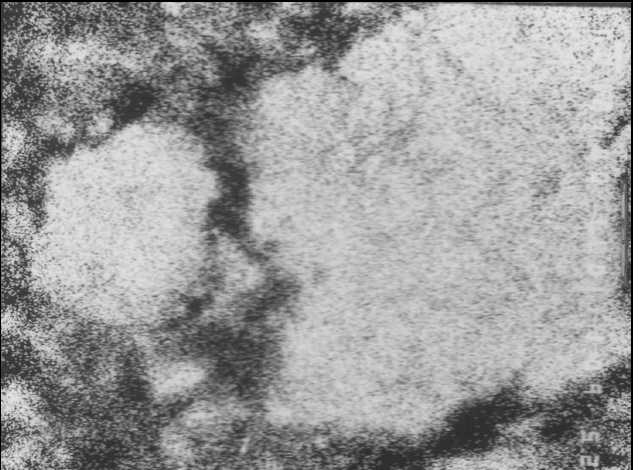

$\mathrm{Si}$

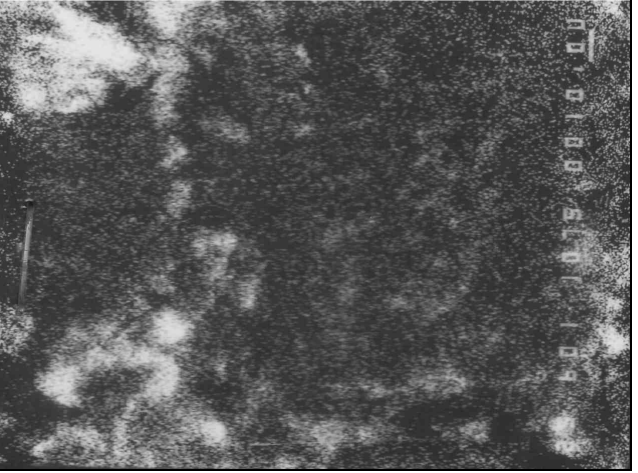

$\mathrm{Al}$

Fig. 2. Characteristic microstructure of slag with the elements distribution map

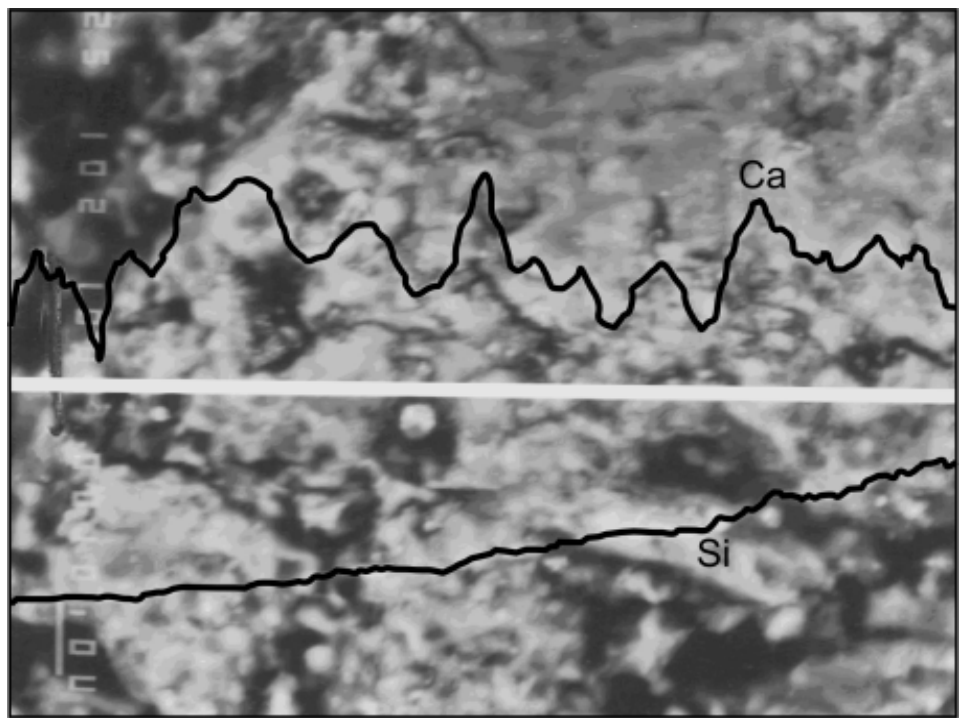

Fig. 3. Microstructure of the slag with the results of line scanning 
Mineralogical composition of unhydrated slag

\begin{tabular}{|c|c|c|c|c|}
\hline Mineral & $\boldsymbol{\gamma}$-2CaO SiO & Periclase & Melilite & Portlandite \\
\hline [wt. \%] & 70 & 18 & 9 & 3 \\
\hline
\end{tabular}

The unhydrated slag granulation is of a very fine powder, presented in Figure 4.

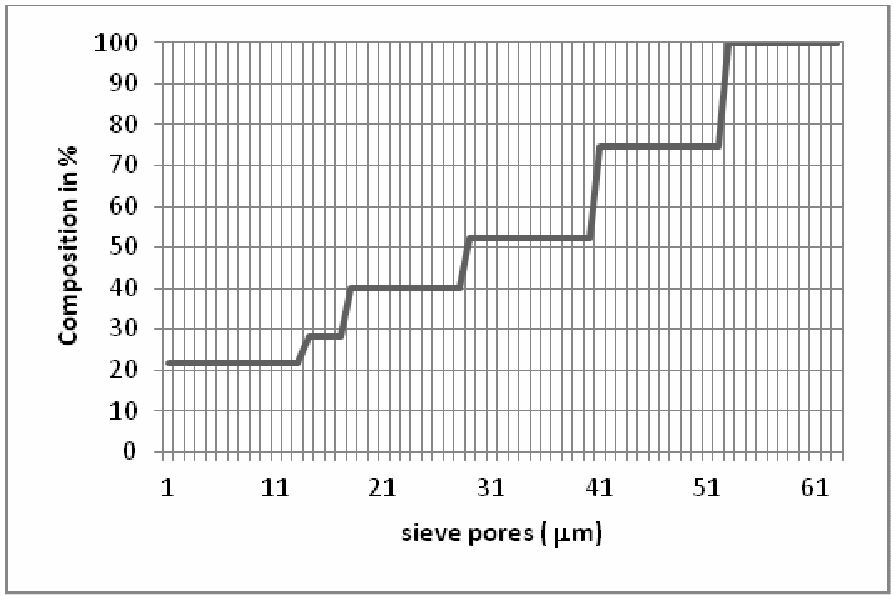

Fig. 4. Granulometric composition of the slag sample

Granulometric composition of the slag is given in Table 3.

Table 3

Granulometric composition of the slag

\begin{tabular}{|c|c|c|c|}
\hline No. & Class $[\mu \mathrm{m}]$ & Weight [g] & Weight [\%] \\
\hline 1 & +53 & 7.57 & 25.23 \\
\hline 2 & $-53+40$ & 6.75 & 22.5 \\
\hline 3 & $-40+28$ & 3.73 & 12.43 \\
\hline 4 & $-28+18$ & 3.46 & 11.53 \\
\hline 5 & $-18+10$ & 1.96 & 6.54 \\
\hline 6 & $-10+0$ & 6.53 & 21.77 \\
\hline \multicolumn{2}{|c|}{ Total } & 30 & 100 \\
\hline
\end{tabular}

The TSP standard requires countries to have an annual geometric mean of TSP concentrations of less than $75 \mu \mathrm{g} / \mathrm{m}^{3}$ and to have no more than one daily reading exceeding $260 \mu \mathrm{g} / \mathrm{m}^{3}$. TSP consist of all particles with diameters less than or equal to 40 micrometers $(\mu \mathrm{m})$. The focus of EU regulation [6] has shifted to particulates with diameters of less than or equal to $10 \mu \mathrm{m}\left(\mathrm{PM}_{10}\right)$ and $2.5 \mu \mathrm{m}\left(\mathrm{PM}_{2.5}\right)$. As it can be seen from Figure 4 and Table 3, the ratio of $\mathrm{PM}_{10} / \mathrm{TSP}=0.103$, and total ratio of TSP in the slag was 0.53 . As the measurements are not performed for a longer period, the limit of $150 \mu \mathrm{g}$ was used as recommended, as the limit set by the WHO requires less than $50 \mu \mathrm{g}$ in not more than three days in a roll. 
To determine dust loading within the range of $5 \mathrm{~km}$ radius, results were used of the measurements conducted on site by inlet probes from 2010 at distances of 300 and 600 meters in all directions from the slag deposit. The results for June $1^{\text {st }}$ are shown in Figure 5 and the results from June $1^{\text {st }}$ to June $10^{\text {th }}$ in 2010 are presented in Table 4.

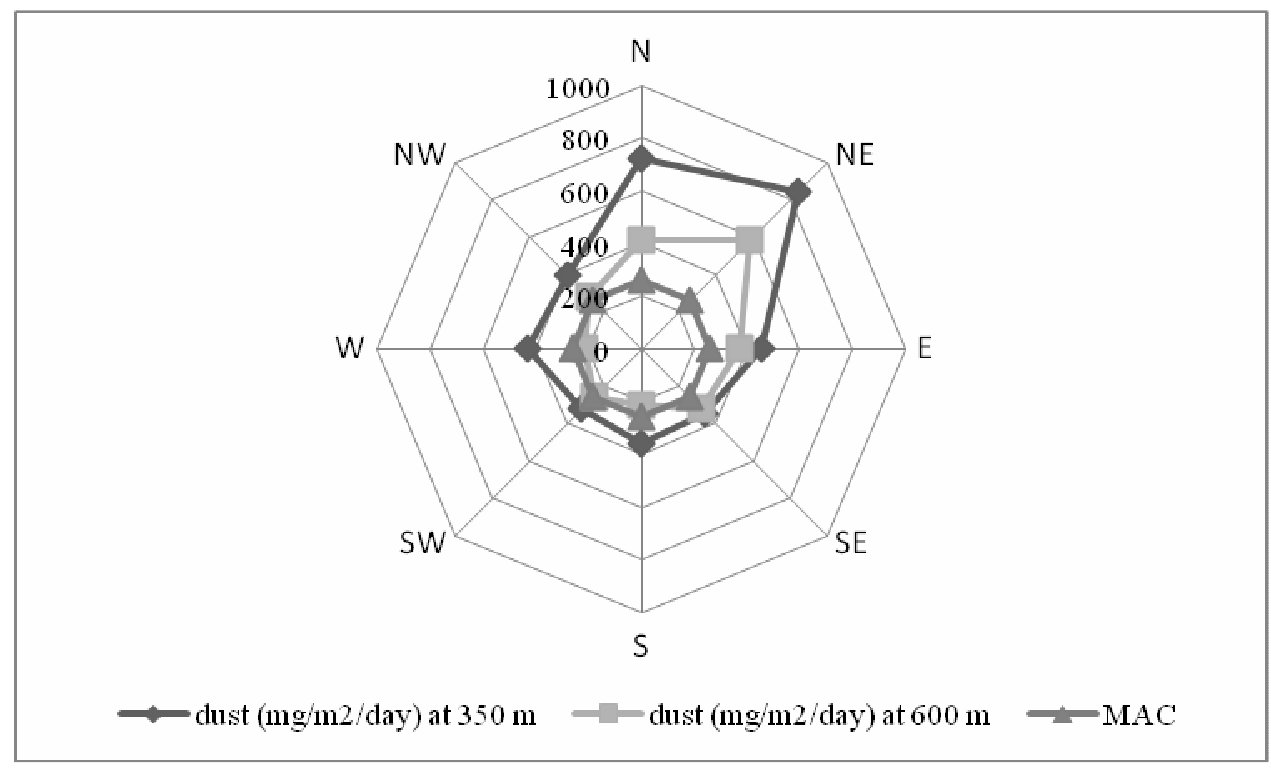

Fig. 5. Diagram of the concentrations of slag dust deposited at two distances from the slag pile

TSP concentration $\left[\mathrm{mg} / \mathrm{m}^{3}\right]$ conducted on site from $01.06-10.06,2010$

Table 4

\begin{tabular}{|c|c|c|c|c|c|c|c|c|c|c|c|c|}
\hline$\frac{\text { Site }}{\text { Date }}$ & \begin{tabular}{|c|}
$\mathbf{N}$ \\
$300 \mathrm{~m}$ \\
\end{tabular} & $\begin{array}{c}\mathrm{NE} \\
\mathbf{3 0 0} \mathrm{m}\end{array}$ & $\begin{array}{c}\mathbf{E} \\
\mathbf{3 0 0} \mathrm{m}\end{array}$ & $\begin{array}{c}\text { SE } \\
300 \mathrm{~m}\end{array}$ & $\begin{array}{c}\mathrm{S} \\
300 \mathrm{~m} \\
\end{array}$ & $\begin{array}{c}\text { SW } \\
300 \mathrm{~m}\end{array}$ & $\begin{array}{c}\mathrm{W} \\
300 \mathrm{~m}\end{array}$ & $\begin{array}{c}\mathrm{N} \\
600 \mathrm{~m} \\
\end{array}$ & $\begin{array}{c}\mathrm{NE} \\
600 \mathrm{~m}\end{array}$ & $\begin{array}{c}E \\
600 \mathrm{~m}\end{array}$ & $\begin{array}{c}\text { SE } \\
600 \mathrm{~m}\end{array}$ & $\begin{array}{c}\mathrm{S} \\
600 \mathrm{~m}\end{array}$ \\
\hline 01.06 & 1.24 & 1.78 & 1.73 & 1.07 & 0.73 & 0.91 & 0.58 & 0.91 & 1.17 & 0.36 & 0.36 & 0.44 \\
\hline & & & & & & & & & & & & 32 \\
\hline & & & & & .29 & & & & & & 58 & .64 \\
\hline & & & & & (I) & & & & & & - & .60 \\
\hline 05.06 & & & & & 0.96 & & 1.2 & 1.05 & .96 & .2 & 0.61 & 0.55 \\
\hline 06.06 & 52 & 78 & 0.56 & 0.65 & 0.29 & 0.52 & 0.31 & 0.52 & 0.5 & 0.33 & 0.27 & 0.14 \\
\hline 07.06 & & & 1.09 & 0.92 & 0.54 & 0.96 & 0.77 & 0.96 & 0.67 & 0.63 & 0.29 & 0.23 \\
\hline 08.06 & 87 & .98 & 1.37 & 1.59 & 1.37 & 0.78 & 0.43 & 0.78 & 0.68 & 0.72 & 0.51 & 0.76 \\
\hline & & & 1.54 & 1.46 & 1.09 & & 0.65 & 0.26 & & 0.69 & 0.34 & 0.70 \\
\hline 10.06 & 1.09 & 1.24 & 1.42 & 1.38 & 0.94 & 1.45 & 0.59 & 1.45 & 0.97 & 0.62 & 0.27 & 0.47 \\
\hline
\end{tabular}

\section{Climate conditions}

As the measurements were performed at a relatively small distance and under the actual climate conditions for the defined period, it was necessary to define the approximate dust loading under different climatic conditions. The initial conditions such as dust load under laboratory conditions, slag characteristics, deposit dimensions and surrounding relief were inputted into the software Screenview and the obtained diagram showed reasonable 
agreement with the measured values. This can be observed, for example, for the results measured on 04.06.2010 for the NE direction at a wind speed of $3.0 \mathrm{~m} / \mathrm{s}$ and a relative humidity of $47 \%$.

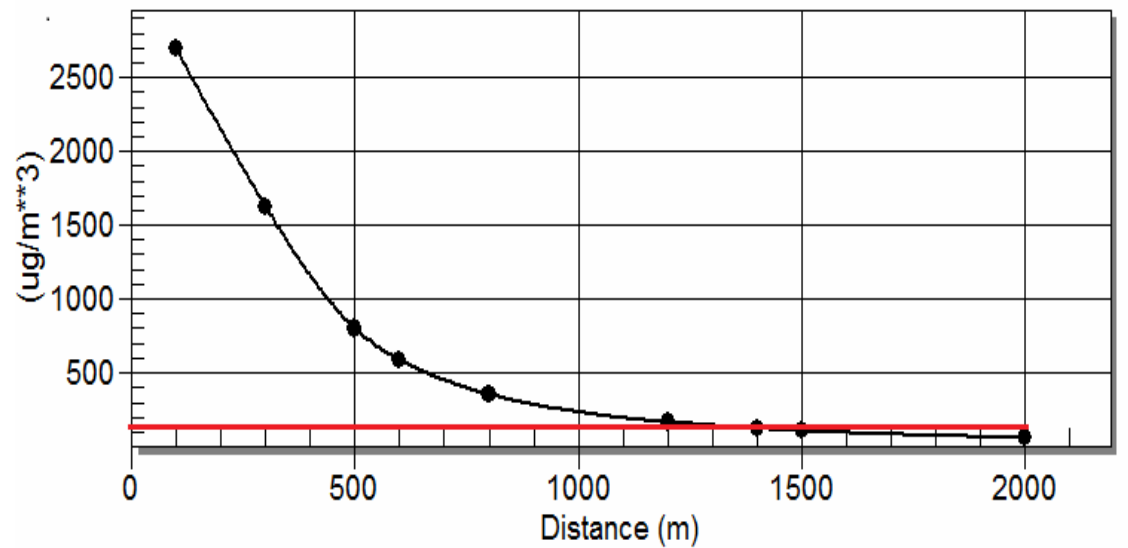

Fig. 6. TSP concentration for the NE direction from the slag deposit at a wind speed of $3.0 \mathrm{~m} / \mathrm{s}$

Considering the climate conditions during the actual measurements, and the data showing the trend in minimum relative humidity, as shown in Figure 7, and a wind speed maximum value of $8.8 \mathrm{~m} / \mathrm{s}$, it was necessary to simulate dust load for the possible climate conditions for the region where the deposit is situated, Figure 8.

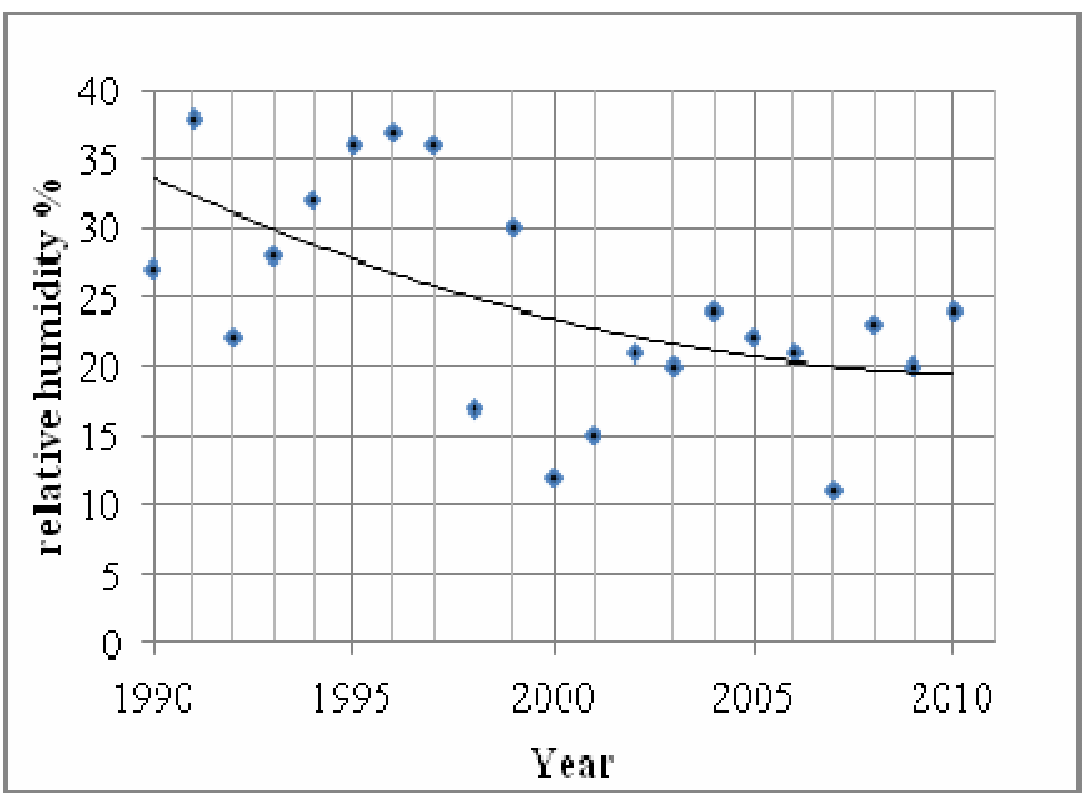

Fig. 7. Minimum relative humidity recorded since 1990 at the Meteorological Station Josanicka Spa 
By analyzing the data for wind speeds, directions and frequencies, it can be concluded that the winds have changed their frequencies over the last 20 years. In 1999, the weather was mostly stable, and just $7.0 \%$ of the winds had a speed of more than $3.6 \mathrm{~m} / \mathrm{s}$. Southern winds were the strongest and northeastern winds were the most frequent, ie, $20 \%$ of the winds came from this direction. Just $1 \%$ of the winds were stronger than $8.8 \mathrm{~m} / \mathrm{s}$. In 2010 , $21.1 \%$ was in the wind class $3.6 \div 5.7 \mathrm{~m} / \mathrm{s}$, and $2.8 \%$ of the winds had a wind speed of more than $5.7 \mathrm{~m} / \mathrm{s}$. Southern winds were the most frequent, but southwestern winds also increased in frequency and speed. This is usually the case in the summer, when strong hot winds blow from the Mediterranean area, with hot and dry weather (Fig. 7, Fig. 8a and b).
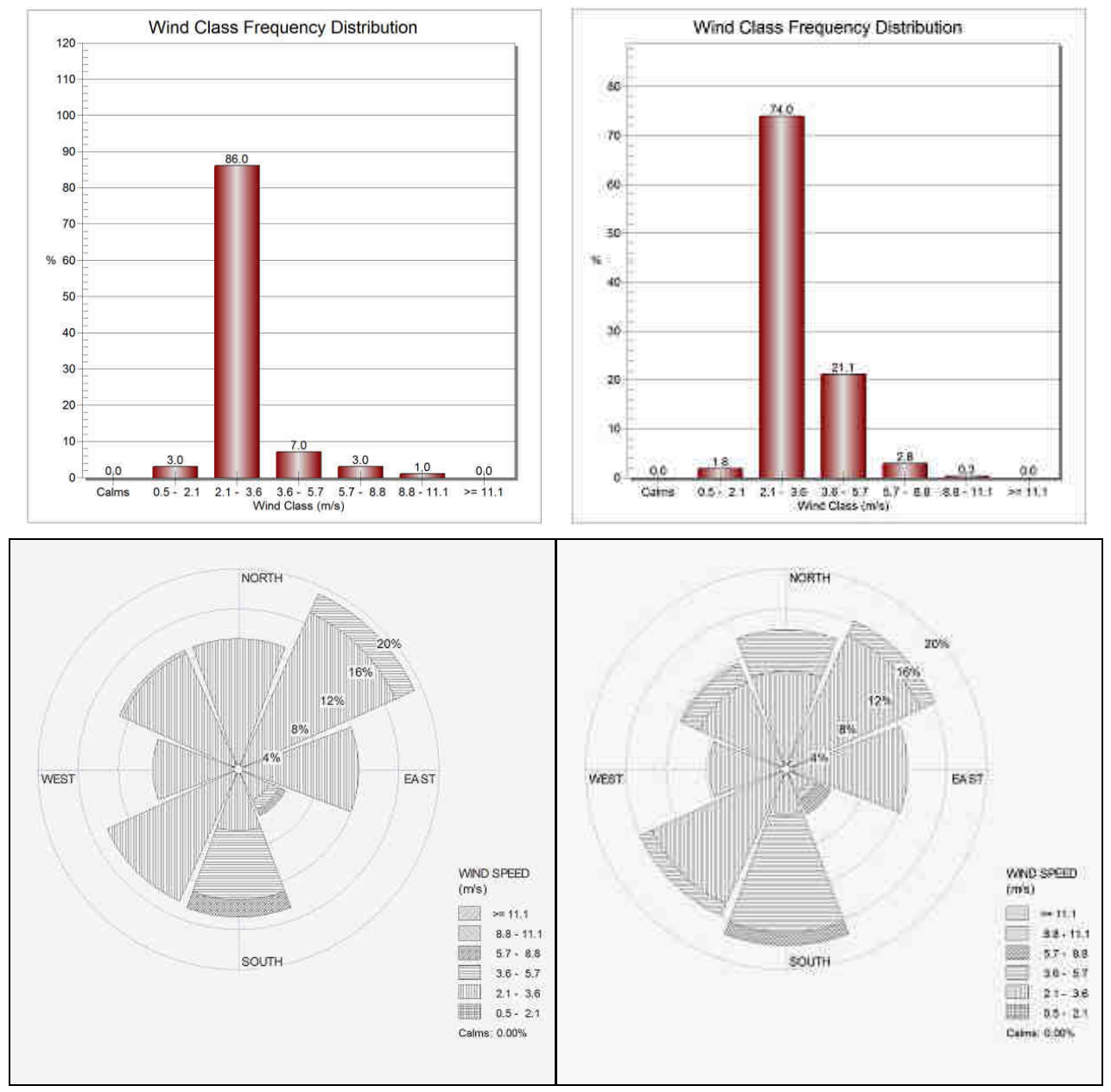

a)

b)

Fig. 8. Wind class frequencies at the Met. Station Josanicka Spa: a) wind rose for 1999 and b) wind rose for 2010 
The graphic presentation was obtained using WRPLOT 7.0.0. software, as shown in Figure 8. By application of a Screenview model, dusting curves were obtained for larger distances and wind speeds of 5,7 and $10 \mathrm{~m} / \mathrm{s}$ in all directions. The dust loading range for a wind speed of $5.7 \mathrm{~m} / \mathrm{s}$ can be seen in Figure 9, showing that a maximum allowed concentration of $150 \mu \mathrm{g} / \mathrm{m}^{3}$ was exceeded even at a distance of $4 \mathrm{~km}$ in the NE direction.

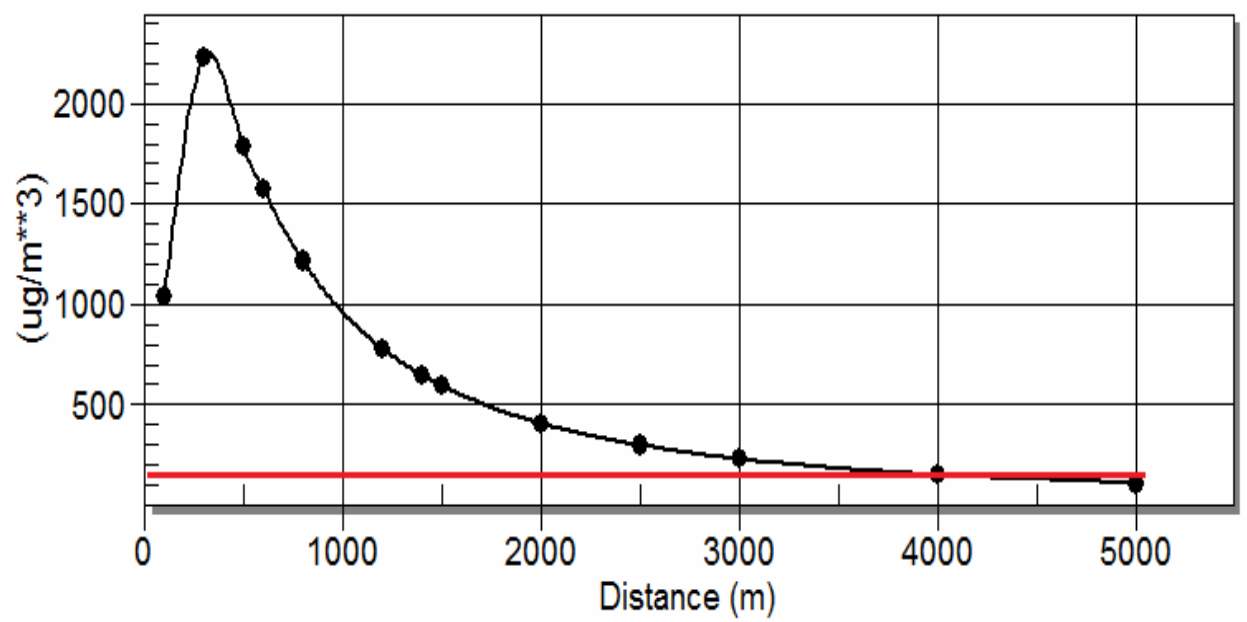

Fig. 9. TSP concentration in the NE direction at a wind speed of $5.7 \mathrm{~m} / \mathrm{s}$

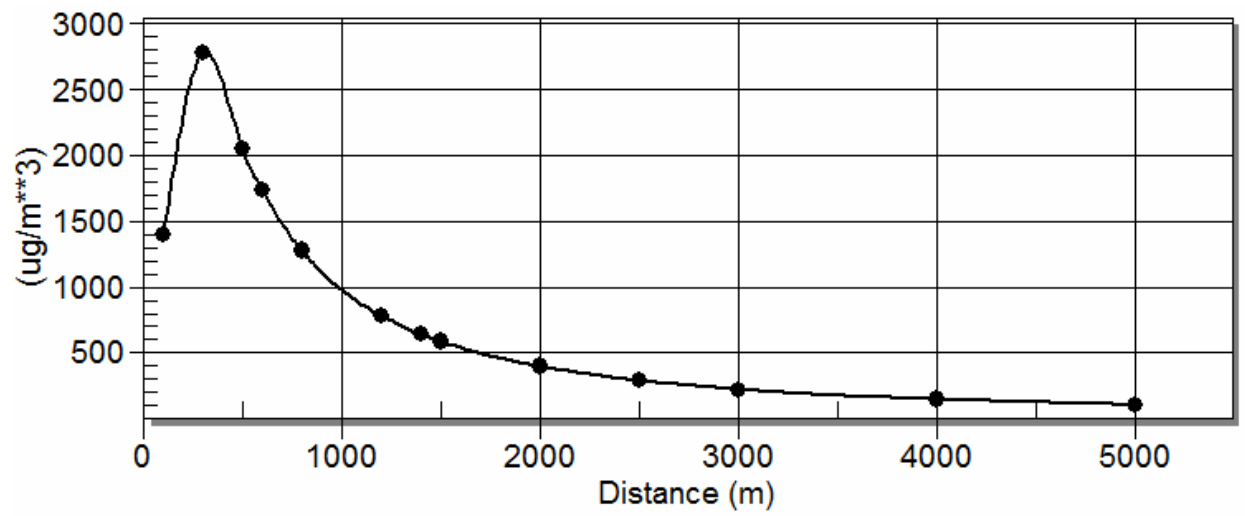

Fig. 10. TSP concentration in the NE direction for a wind speed of $8.8 \mathrm{~m} / \mathrm{s}$

Taking into consideration all the wind classes, the results of airborne dusting $\left[\mathrm{mg} / \mathrm{m}^{2}\right]$ in the laboratory, as initial data, for a relative humidity from $14 \div 40 \%$, are presented in Figure 10. 


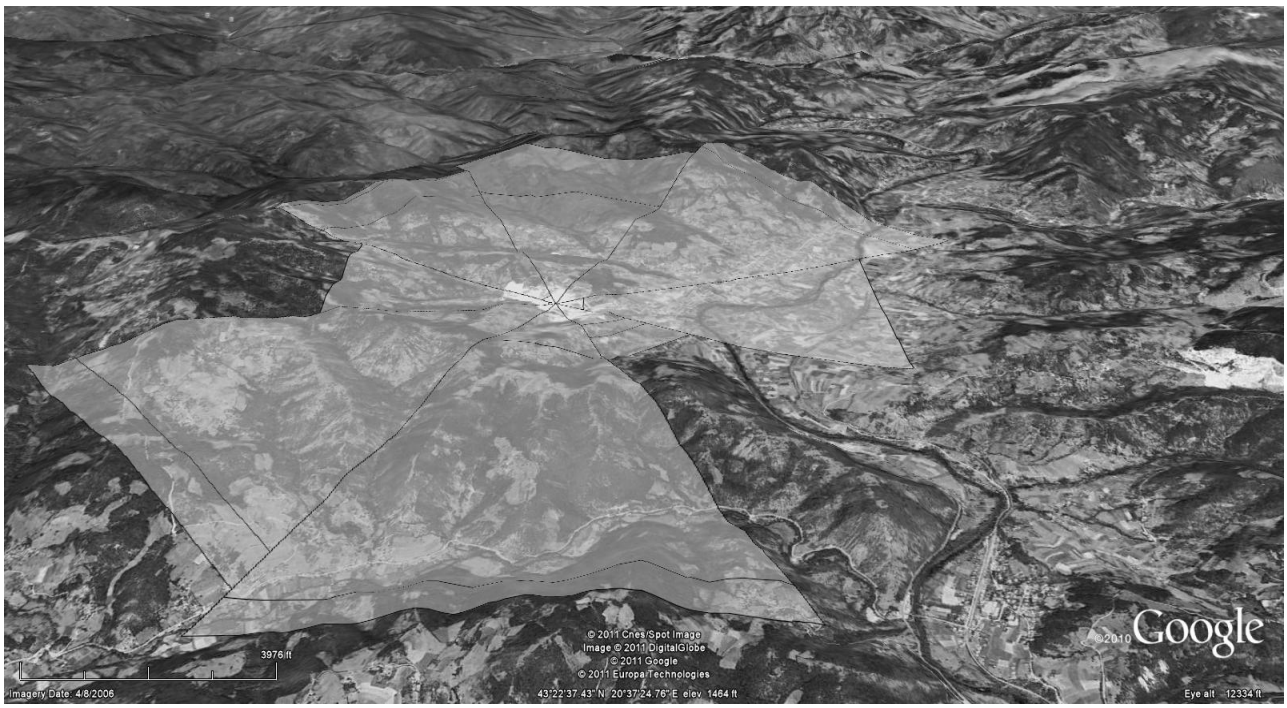

Fig. 11. Graphic presentation of the wind rose from the magnesium slag deposit within a range of $4 \mathrm{~km}$ (WRPLOT 7.0.0 exported graphic)

\section{Conclusions}

The non-hydrated slag from the silicothermic process of magnesium production was proven to have a great environmental impact, due to its form, fine grains of $\mathrm{PM}_{10}$, and TSP. Under stable weather conditions, the dust load is scattered by up to $1400-2000 \mathrm{~m}$ around the slag deposit. With climate change, ie, decreased relative humidity and the frequency of strong winds $(3.6 \div 5.7 \mathrm{~m} / \mathrm{s})$ reaching $21.9 \%$, with $1 \%$ of the winds attaining a speed of $8.8 \mathrm{~m} / \mathrm{s}$, the impact range was wider. Thus, a larger area, up to $5 \mathrm{~km}$ in diameter, is endangered but because of the topography of the area, the National Park Kopaonik and the Spa on the mountain are unaffected.

\section{Acknowledgements}

This research was conducted as a part of the project III 43007 Global Climate Change Impact to the Environment: Adaptation, Mitigation, which was supported by the Ministry of Education and Science of the Republic of Serbia.

\section{References}

[1] WHO Air quality and health, Fact sheet No. 313 (2008)

[2] Peck P. Desk-assessment study for the Environment and Security Initiative Project UNEP Regional Office for Europe \& UNEP Division of Technology, Industry and Economics; 2004.

[3] Araújo LA. Manual de Siderurgia'1st Edn. São Paulo, Brasil;1997.

[4] Pietersen HS. Application of TEM to characterize fly ash- and slag cements. Heron. 1999;44(4).

[5] Minic D, Manasijevic D, Djokic J, Zivkovic D, Zivkovic Z. Thermal Analysis and Characterization of the Slag of the Silicothermic Reduction Process in Magnesium Production, J Thermal Analysis and Calorimetry. 2008;93(2):411-415. DOI:10.1007/s10973-006-6563-0. 
[6] Djokic J, Minic D, Kamberovic Z. Reuse of metallurgical slag from the silicothermic magnesium production and secondary lead metallurgy. Metalurgia Int. 2012;17(3):46-52.

[7] Jimenez-Guerrero P, Perez C, Jorba O, Baldasano JM. Contribution of Saharan dust in an integrated air quality system and its on-line assessment. Geophysical Res Letters. 2008;35. DOI:10.1029/2007GL031580.

[8] Directive of the European Parliament and of the Council on ambient air quality and cleaner air for Europe $\{$ SEC(2005) 1133\}, Annex XII.

\title{
WPLYW ŻUŻLU Z PRODUKCJI MAGNEZU \\ I ZMIAN KLIMATYCZNYCH NA ZANIECZYSZCZENIE POWIETRZA
}

\begin{abstract}
Abstrakt: Analizowano wpływ żużlu z produkcji magnezu na zanieczyszczenie powietrza w różnych warunkach klimatycznych. Żużel scharakteryzowano z wykorzystaniem rentgenowskiej analizy dyfrakcyjnej, skaningowej mikroskopii elektronowej, różnicowej analizy termicznej i atomowej analizy absorpcyjnej. Dominującą fazą była modyfikacja $\gamma$ z krzemianu dwuwapniowego $\left(\gamma-2 \mathrm{CaO} \mathrm{SiO}_{2}\right)$ ze znaczną ilością $\mathrm{MgO}, 2 \mathrm{CaO} \mathrm{Al}_{2} \mathrm{O}_{3} \mathrm{SiO}_{2}, 2 \mathrm{CaO}$ $\mathrm{MgO} 2 \mathrm{SiO}_{2}$ i Ca(OH)$)_{2}$. Skład granulometryczny żużlu obejmował przedział $100 \times 10^{-3} \div 0,090 \times 10^{-3} \mathrm{~m}$. Pomiary, wykonane in situ w czerwcu w odległość 300 i 600 m od miejsca złożenia żużla, pokazały duże stężenia cząstek zawieszonych (TSP). Porównanie danych doświadczalnych z modelem emisji implementowanym w programie SCREENVIEW, przy założeniu prędkości wiatru wynoszącej 5, 7 i $10 \mathrm{~m} / \mathrm{s}$ oraz w zakresie wilgotności względnej $10 \div 50 \%$, wykazało dobrą zgodność obu wyników. Symulacje, które uwzględniały zmiany krajobrazu i prędkości wiatru w ponad 20-letnim okresie, wykazały, że stężenie pyłu przekracza maksymalne dopuszczalne stężenie (MAC) w odległości do $1400 \mathrm{~m}$ od depozytu, przy średniej prędkości wiatru 3,0 m/s, wilgotności względnej $37 \%$ i do $4000 \mathrm{~m}$ w niestabilnych warunkach pogodowych.
\end{abstract}

Słowa kluczowe: żużel magnezowy, zanieczyszczenie powietrza, emisja pyłu, modelowanie 